eCommons@AKU

THE AGA KHAN UNIVERSITY

AKU-East Africa

Institute for Educational Development, East Africa

January 2010

\title{
Home and school literacy practices in africa: listening to inner voices
}

Jacob Marriote Ngwaru

Aga Khan University, marriote.ngwaru@aku.edu

Kwasi Opoku-Amankwa

Kwame Nkrumah University of Science \& Technology (KNUST), Kumasi, Ghana

Follow this and additional works at: http://ecommons.aku.edu/eastafrica_ied

Part of the Bilingual, Multilingual, and Multicultural Education Commons, and the Elementary and Middle and Secondary Education Administration Commons

\section{Recommended Citation}

Ngwaru, J. M., Opoku-Amankwa, K. (2010). Home and school literacy practices in africa: listening to inner voices. Language and Education, 24(4), 295-307.

Available at: http://ecommons.aku.edu/eastafrica_ied/20 


\section{Home and school literacy practices in Africa: listening to inner voices}

\section{Jacob Marriote Ngwaru \& Kwasi Opoku-Amankwa}

To cite this article: Jacob Marriote Ngwaru \& Kwasi Opoku-Amankwa (2010) Home and school literacy practices in Africa: listening to inner voices, Language and Education, 24:4, 295-307, DOI: 10.1080/09500781003678985

To link to this article: http://dx.doi.org/10.1080/09500781003678985

册Published online: 01 Jun 2010.

Submit your article to this journal

Џll Article views: 257

Q View related articles ๘

4 Citing articles: 6 View citing articles ๘ 


\title{
Home and school literacy practices in Africa: listening to inner voices
}

\author{
Jacob Marriote Ngwaru* and Kwasi Opoku-Amankwa ${ }^{\mathrm{b}}$ \\ ${ }^{a}$ Institute of Education, National Centre for Language and Literacy, University of Reading, Reading, \\ $U K,{ }^{b}$ Department of Publishing Studies, Kwame Nkrumah University of Science \& Technology \\ (KNUST), Kumasi, Ghana
}

(Received 29 July 2009; final version received 9 September 2009)

\begin{abstract}
The voices of the main stakeholders in literacy and schooling - pupils and parents have seldom been given adequate space in studies of school and classroom discourse in sub-Saharan Africa. The present paper attempts to redress this imbalance by presenting the voices of pupils from a multilingual urban primary school in Ghana and of parents from a rural bilingual school in Zimbabwe. The Ghanaian study highlights challenges associated with using an unfamiliar language, English, as the medium of instruction, selective teacher treatment in the classroom that leaves some children lacking confidence to participate and the strong influence of the home environment and other socio-economic conditions. The Zimbabwean study highlights what happens when parents are allowed a voice in their children's education. It is argued that pupil and parent perspectives can validate the findings of existing research, deepen our understanding of classroom interaction and, in some cases, challenge conventional wisdom.
\end{abstract}

Keywords: classroom interaction; safe talk; parent participation; school-parent partnership; mother-tongue education

\section{Introduction}

A growing number of studies address teaching and learning in sub-Saharan African classrooms. Far too often, however, these studies are based on the observations of researchers who fail to give a voice to two important groups of stakeholders in education - parents and children. The aim of the present study, in contrast, is to broaden the debate to include these important players in order both to build a picture of the challenges faced by the sub-Saharan African education systems and to point to promising ways forward. We start by reviewing previous studies of education in sub-Saharan Africa which provide the backdrop for the present discussion. Then we draw on two recent studies which foreground the voices of these key players. The first (Ngwaru 2008) concerns an urban classroom in Ghana which invites children to express their views on why formal schooling fails to meet their needs; the second (Opoku-Amankwa 2008) considers the merits of including parents as participants in discussions of their children's education as part of a study of literacy learning in rural Zimbabwe.

\section{Previous studies of African education}

Much of the early research on education in sub-Saharan Africa repeatedly asks the question of how classroom factors - teachers, teaching learning materials and so on - influence

*Corresponding author. Email: mngwaru@yahoo.com 
child achievement (Daley et al. 2005). One strand of this research focuses on educational resources. Heyneman, Farrell, and Sepulveda-Stuardo (1981), for instance, conclude that compared with commonly measured potential correlates of school achievements, such as teacher training and class size, the availability of books has consistently been associated with higher achievement levels. Similarly, Heyneman and Jamison (1980) attribute improvement in pupils' language abilities largely to a high textbook-to-pupil ratio. Studies by Altbach and Kelly (1988), Farrell and Heyneman (1989), Fuller (1987) and Fuller and Snyder (1991) also underline the potential of book projects as key vehicles for the cost-effective improvement of the quality of education in developing countries.

Another strand has focused on teacher effectiveness, with researchers identifying as key factors lesson clarity, instructional variety, use of teacher time and high levels of pupil engagement (Creemers 1994; Ackers and Hardman 2001). These studies tend to suggest that the quality of teacher-pupil classroom interaction is the single most important factor accounting for wide differences in outcome measures using the same curriculum materials and, purportedly, the same teaching methods (Ackers and Hardman 2001).

Most of these studies, however, fail to take into account the ecological and socio-cultural conditions of economically disadvantaged communities and how such factors affect education and literacy development. As Neuman and Celano (2001) clearly point out, learning and development cannot be considered apart from the individual's social environment and eco-cultural niche. For instance, it can be argued that by relying on standardised school examinations to measure achievement, Heyneman, Farrell, and Sepulveda-Stuardo (1981) and Heyneman and Jamison (1980) underestimate the importance of factors such as home, family background and parental perception of the legitimacy of schooling as predictors of school outcome. These studies thus tend to follow the production-function model, according to which learning, or student achievement, is an 'output' of a system that processes a number of 'inputs' such as teachers, books and school facilities (Daley et al. 2005). There has also been an increasing recognition of the importance of process variables such as style of teaching in the considerations of school quality (Daley et al. 2005).

More recent qualitative approaches to research include socio-political analysis and analyses of classroom interaction. A variety of socio-cultural, socio-economic, political and linguistic factors have been identified as important predictors of academic outcomes ( $\mathrm{Au}$ 1998; Cummins 2001; Baker 2001, 2006; Martin 1999). Some studies, for example, have questioned why quality of education in sub-Saharan Africa continues to decline in spite of the heavy investment in education of post-colonial African governments, pointing to a range of factors in addition to financial constraints. These include the imported bureaucraticauthoritarian educational model of nineteenth-century Europe (Tabulawa 1997), the African elites' belief in the supremacy of western civilisation and culture (Brock-Utne 2001) and the absence of refresher and continuing professional development programmes in the educational and human resource policies of post-independence African countries (Christie, Harley, and Penny 2005). Other studies have considered the frustrations that African reformists encounter in their attempts to promote vocational and technical education which can be seen as relevant to the needs of the society (Osei 2003).

Studies focusing more specifically on classrooms have addressed issues relating to language practices in multilingual and/or post-colonial contexts. These studies mark a shift from a quantitative, positivist approach to a qualitative, constructivist approach based on in-depth analyses of classroom practices. Sub-Sahara African classroom studies in this category include Chick's (1996) seminal work on safe talk in a South African classroom. Safe talk is a type of chorusing and patterned classroom talk which allows participation without risk of loss of face for the teacher and the learners and maintains an appearance of 'doing 
the lesson'. The participants in the classroom thus collude to hide the unpleasant reality of their poor command of a former colonial language that is the medium of instruction. Bunyi (1997, 2005), on the other hand, focuses on code switching in Kenyan classrooms, showing how teachers switch between English and Kiswahili to explain texts, elaborate a point and provide pupils who have limited knowledge and control over the language of instruction with access to the curriculum. Rubagumya $(1990,1993)$ and Alidou and Brock-Utne (2005) discuss the benefits of mother tongue literacy in classrooms in Tanzania, where when English was used students were silent and grave and teacher talk dominated the lessons. In contrast, lessons taught in the local language were interactive, and students participated fully, were self-confident and believed in themselves and their learning potential. Andoh-Kumi (1998) and Wilmot (2003) confirm the relevance of learning in a familiar language in studies in Ghanaian classrooms where they independently observed that students perform better in mathematics and general science, offer clear explanations and demonstrate competence in abstract thinking when taught in the local languages rather than in English. Similarly Ejieh (2004) notes of a six-year mother tongue education programme (the Ife Mother Tongue Project) in Nigeria that the cultural, affective, cognitive and socio-psychological development of children attending the Ife Project was more advanced than that of their counterparts attending the regular schools. These studies, while providing deeper insight into the workings of sub-Saharan African classrooms than the earlier quantitative studies, fail to give adequate space to the voices of key stakeholders, including parents and pupils.

\section{Background to the study}

The larger studies from which student and parent voices have been extracted (Ngwaru 2008; Opoku-Amankwa 2008) both use a qualitative research design, involving home and school observations, interviews, focus group discussions with parents, teachers and pupils and analyses of documents. The interviews and focus group discussions create a space for the parents and children to voice their own interpretations and thoughts, as well as frustrations, rather than relying solely on 'outsider' interpretations. In other words, they are encouraged 'to tell their side of the story in their own words' (Dei 2005; Eder and Fingerson 2002). The Ghana study focused on a Primary Four class in a multi-ethnic suburban community in Kumasi, the second most populous and ethnically diverse city in Ghana. The pupils formed a very heterogeneous group. The Zimbabwe case study looked at literacy practices at home and school in a more homogeneous rural setting with a particular focus on six families and their 25 primary school-going children.

\section{The Ghana study}

Observation and interviews with children at Tomso, the case study school in Ghana, raised important issues concerning competence in English, the selective treatment of pupils by the teacher and literacy learning in the home. In some cases, these findings strengthen existing critiques of African classrooms; in others they throw new light on our understanding of teaching and learning in these settings.

\section{Competence in English}

Ghana is a multilingual/multi-ethnic society with approximately 44 local and cross-border languages (Hall 1983), where English, the former colonial language, is the medium of 
education. Many pupils at Tomso, however, believe that this policy and their teachers' negative perceptions about their competence in the language prevent them from actively participating in classroom activities.

The challenges associated with using English were illustrated when Amakpor arrived late for an English language lesson. When the class teacher, clearly irritated, asked him, 'Are you now coming to school?', Amakpor stood speechless until the teacher chastised him and asked him to sit down. Later in the lesson it became evident that Amakpor and many other pupils in the class had limited access to English, the language of instruction. Amakpor, for example, could not point to hers from a list of words, including theirs, mine, his and ours, while Steve and Mike failed to form correct sentences with hers:

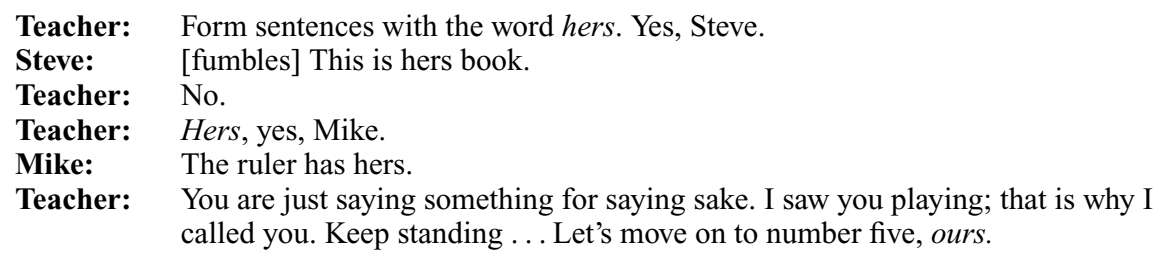

When interviewed at a later point, in Twi, the local language of the area, Amakpor frankly indicated that he failed to give reasons why he was late because, 'I couldn't say it in English. Madam would insist that I say it in English'. The school policy is that pupils speak English at all times; it is one of the 10 point norms pasted in each classroom: 'Speak English both inside and outside the classroom'.

Amakpor, like many other children in Primary Four, is multilingual; in addition to Ewe, his mother tongue, he is also a fluent speaker of two local languages: Twi, the language of the school community, and Ga. However, in school Amakpor is considered a weak pupil largely because he is not able to communicate in English. This is a source of worry:

I need more encouragement and special attention and when I don't understand, teacher should explain in Twi for me. My teachers do not encourage me; rather they make me dislike school. When teacher asks me a question and I'm not able to answer she whips me or she'll make a negative remark which completely puts me off from coming to school regularly.

Badua, whose first language is Twi, shared a similar view: 'It is difficult to follow lessons in English. I enjoy lessons when teacher uses Twi to explain things'. Asantewaa, for her part, recognises the importance of English but feels the need for support from school:

I speak just a bit of English. I need to pay particular attention in class when the teacher is teaching. I have a book at home but I do not get time to read and nobody encourages me to read. When I'm reading my mother will rant at me and say, 'Lazy girl, come and wash the things' or 'Go and fetch water'. In the evening I get tired and I don't read; I watch television.

Another student, Bella, discloses that she never speaks in class and indicates that she goes blank when English is spoken. These pupil perspectives, then, add indirect support for advocates of bilingual education and for writers such as Cummins (2001), Ramirez, Yuen, and Ramey (1991) and Thomas and Collier (2002), who argue that the longer the children are educated through the medium of their mother tongue, the better the academic results. Conversely, children educated through the medium of an unfamiliar language are likely to struggle in their attempts to understand and access curriculum content. 


\section{Selective teacher treatment}

Another issue on which pupils were able to throw light is the role of more competent peers in classroom interactions. In the Ghanaian case study classroom, only half a dozen or so of the 74 pupils are considered to be very good; these are pupils who, according to the class teacher, 'are able to read fluently and without the teacher's intervention'. They usually act as leaders during group reading exercises, and most class interactions revolve around them. At the other extreme are pupils such as Amakpor, Bella, Tsatsu, Mike, Musa and others who are classified as weak. Only occasionally are they called to participate in class activities. The teacher spends little time with them, especially when they fail to give instant and 'correct' answers and often makes comments such as this: 'You can't waste our time'. Sometimes these children were caned before the teacher called on a more 'competent' pupil to read.

In the following extract from a lesson on prepositions, for example, we see how the teacher gives praise to some pupils, while the contributions from other pupils pass unnoticed or receive a negative comment:

Teacher: Where is the teacher? Yes, Theo ...

Theo: The teacher is in front of the class.

While Theo's observation was accurate, it was not the answer required by the teacher, who wanted her position to be described in relation to the blackboard and not the class. So Theo receives no commendation and the teacher moves on to one of the high-achieving students:

Teacher: Who can say it well? Yes, San ...

San: $\quad$ The teacher is in front of the chalk board.

Teacher: Chalkboard and blackboard, they're the same thing, clap for her.

Class claps

Teacher: Let's take this as oil. I've put the oil somewhere.

Teacher puts a bottle under a table

Sammy: The oil is under the table.

Teacher: Where is the oil?

All: $\quad$ The oil is under the table.

It is notable here that although Sammy's answer is correct and the teacher invites the class to repeat the answer, this underachieving pupil does not receive the same level of recognition as San. The following extract also confirms the teacher's selective attention:

Teacher: $\quad$ Tabiwaa, stand behind John.

Tabiwa does not understand 'behind'. The teacher shouts out, 'Stand behind John'. Tabiwa moves round John and stands in different positions. The teacher positions her behind John.

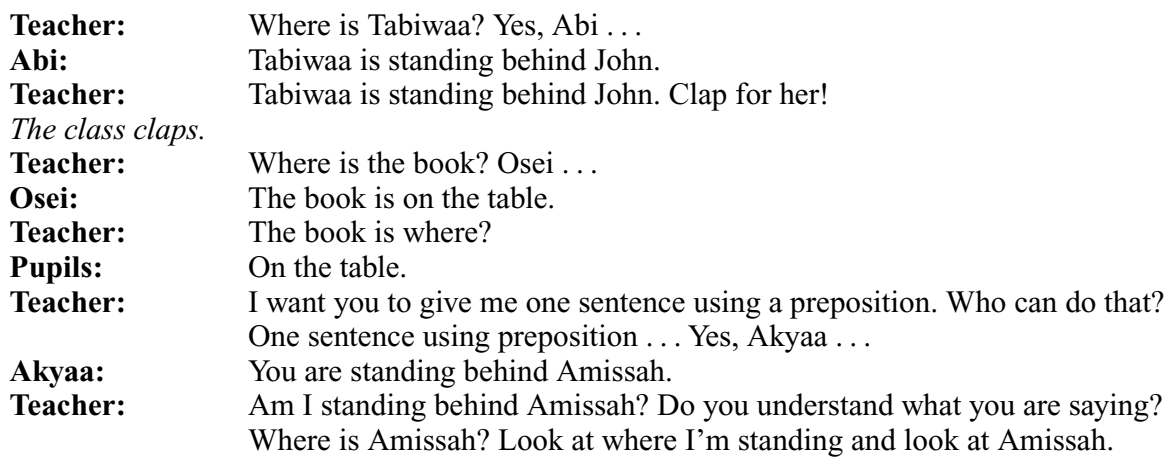


It is obvious that the pupil does not understand what she was saying. The teacher turns her attention to another student.

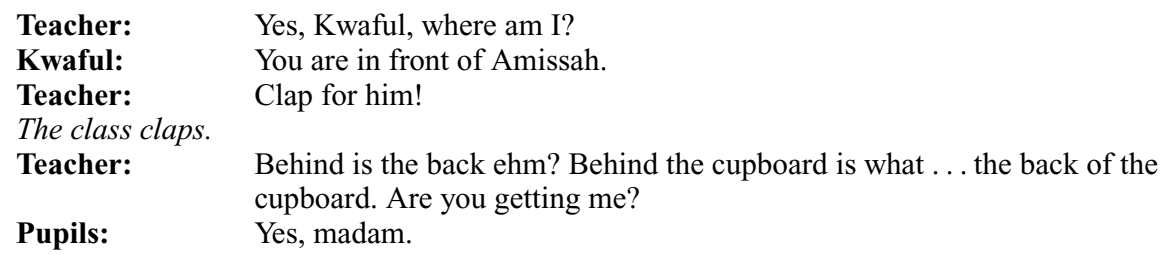

Akyaa's contribution was correct and a bold attempt for someone who scarcely speaks in class; it would have been a boost for her if the teacher had accepted the sentence and praised her. However, because she failed to use the preposition in front, the teacher would not accept her answer.

In focus group discussions, the pupils raised concern about their teacher's selective attention to pupils. Akosei confidently discloses, 'I'm a good student but madam fails to call me'. She, like many others who are seldom invited to contribute to class discussions, sees San, Abi and Franky as her teacher's pets: 'They are the pupils teacher always calls to send, to read in class or give out and collect books'. Other issues highlighted by the children included the teacher's use of the cane and the lack of access to books for their own use in school or to take home. Their major grievance, however, focused on the perceived selective treatment by the teacher.

While analyses of classroom interaction which highlight safe talk (e.g. Chick 1996) do so from the perspective of the outside observer, these pupil voices help us to understand student motivation and resistance. As Johnson $(1995,40)$ points out, students' perceived views about classroom events affect their participation in many ways:

It is believed that students' perceptions of classroom events mediate the effects of teaching. That is, students' perception of themselves, their teachers and classroom events and their role in those events acts as filter between what is taught and what is learned ... the extent to which children believe that success in school is possible is a critical factor in the achievement of academic success.

Pupils interpret and read meanings into teachers' facial expressions, voice pitch, and body posture and are highly sensitive to teachers' selective attention (Bloome et al. 2005). There is also evidence that students perceive teachers as having high expectations for high-achieving students, granting them freedom of choice and greater opportunities, while having low expectations for low-achieving students to whom they give more direction and negative feedback (Johnson 1995). In a similar vein, Williams and Snipper (1990) argue that because of the peculiar self-fulfilling dynamic between teacher expectations and student achievement, students who receive negative feedback from teachers indeed tend to perform at a low level.

\section{Home environment and literacy learning}

To understand and further appreciate the plight of the majority of pupils we also need to explore the possible influence of socio-economic conditions on literacy learning (Neuman 1999; Neuman and Celano 2001). The stories of three pupils in our case study class provide us with deeper insights and a better understanding of the conditions under which most children at Tomso Primary come to know and experience literacy.

Amakpor lives with his parents and two other siblings in a compound house with a courtyard open to the sky and leading to rooms either directly or through a veranda or 
porch. About seven households and a total of perhaps 50 people live here. He and his family share two rooms, a living room and a bedroom. The house lacks basic facilities such as electricity, portable water and a toilet. Amakpor is not a regular school attendee, for which he blames his father:

He is more interested in me helping him in his carpentry shop ... [M]y mother is interested in my schooling, but she is not in the position to help. She doesn't work and depends solely on my father ... I do not have any books at home. I'm aware that we can ask to take the books home, but none of my parents will be prepared or willing to come and guarantee for me to take a book home. My older brother and younger sister are no better than me. My older brother dropped out of school about a year ago, and he now works full time with my father in the carpentry shop. Like me, my sister is also not punctual and regular to school.

Fatyah, another pupil in the case study class, lives in conditions similar to Amakpor's. At 10 years of age, she is the fifth of her mother's 10 children. Not surprisingly, the resources of Fatyah's father are overstretched. Fatyah's mother has to rely on her own meagre resources to take care of her 10 children. Fatyah is potentially a good student, but neither home nor school conditions support her. In particular, she identifies access to school books as a concern. The Ghanaian policy is that textbooks in key subjects should be provided on a one-to-one ratio and that children should be able to take them home. In reality, however, pupils in the Ghanaian case study classrooms have limited access to the books (Ngwaru 2008). 'I have no access to any other learning materials apart from the books in school' and, like many other students, she discloses, 'I'm not aware that we can borrow the books and take them home. Teacher has not informed us about that'. A wide range of factors determine pupils' access to literacy, including classroom dynamics, class size, seating arrangements, classroom norms and culture and teachers' understanding and interpretation of the official textbook policy.

Prisca and her younger brother, who is five years old, live with their mother, a single parent. There is no electricity in her house and 'sometimes I learn with a lamp at home'. But she spends much of her time at home helping her mother to make and sell kenkey (a local Ghanaian food prepared with fermented corn dough) in the evenings, and reading is not a high priority. She also did not know that they could borrow schoolbooks to take home to read.

The socio-economic conditions of these children reflect the settings in which literacy and learning generally begin for the majority of the pupils, and their conditions obviously have important consequences for school literacy learning. By including pupil voices, this study clearly illustrates the potential for dialogue between school and home in terms of moving things forward.

\section{The Zimbabwe study}

The Zimbabwean study also highlights the importance of looking outside the classroom in order to understand the constraints on pupil learning. Interviews with parents refer repeatedly to what can be termed their 'ruling passions' (Barton and Hamilton 1998). Before settling to talk with the researcher, for example, about their children's schoolwork, they focused on what they considered the more pressing issues in their lives. There was no lighting at night in the form of electricity, candles or paraffin lamps, and there was no interaction around schoolwork, since parents were clearly preoccupied with the challenges of making ends meet, leaving too little time for any other activities. The major concern for parents, then, was poverty and not literacy. The main issue which we wish to raise in relation to the teaching and learning in the Zimbabwean setting, however, is what happens when parents are allowed a voice in their children's education. 
While the central role of parents in children's educational development has been recognised in many western countries since the 1980s (Rabušicová and Emmerová 2002; Nutbrown, Hannon, and Morgan 2005), in sub-Saharan Africa this awareness has yet to take root. In western countries parents are commonly viewed as a very important part of the educational triangle which consists of the child, teacher and parents. Hurst and Joseph (1998), for instance, view the coming together of parents and practitioners as 'sharing education'. They argue for an understanding of the complex cultural differences and shifts which children, parents and practitioners experience when they enter each other's worlds where there are opportunities for sharing. For Wolfendale (1983), partnership involves parents as active and central figures in the process of decision-making about their children's education; their authority and expertise complement those of teachers, and they are able to share responsibility with 'experts'. Within this framework parents are thought of both as educational partners of the school (defined as individuals and groups entering into relationships with the school because they are interested in their children, their upbringing and education) and as social partners (defined as individuals and groups entering relationships with the school because they are interested in the development of the school as an institution) (Rabušicová and Emmerová 2002).

Such discourse is not, in our experience, a feature of sub-Saharan African schools. It certainly did not inform the thinking of parents and teachers in the rural primary school which formed the focus for the Zimbabwean study. In the early stages, teachers at this school expressed the opinion that parents had nothing to offer to the literacy development of their children. Such views, it can be argued, reflect underlying negative coercive relations of power, informed by the 'imported bureaucratic authoritarian' and elitist belief that the school is superior to the home (Harley and Penny 2005). In a similar vein, interviews with parents suggested that they did not perceive themselves as active social partners of the school. They had reported, rather, that they had no role to play, that they were preoccupied with pressing socio-economic hardships and were more than happy that the teachers knew what they were doing. Mr Ripei, the father in one of the case study families, had this to say:

I know you want us to talk about the education of our children, but you will appreciate we want to tell you about our problems so that at least you know the challenges we face everyday. I live with my wife and children, and I am not of good health at all ... Back to your question about the children and school work, we do support the school and wish teachers all the best as they do a wonderful job. We find our children learning very well, and even one of my little shy girls is now slightly improved, and I attribute all this to the wonderful work that teachers do.

Asked more specifically at a later point whether they participated directly in their children's schooling, Mr Ripei offered, 'No, we do not know anything about what happens at school ... We help by forcing them to go to school because they do not know the importance of schooling'. And, further asked about their involvement at school, he pointed out, 'Only when there was a parent's day when we were invited: otherwise we just send them to school, since we have confidence in what teachers do'. Similarly, when Mr Masona, the household head of another of the case study families, was asked to explain his views about children's schooling, he said:

I respect school education because it instils discipline and self-control. The school assists the family. We work together, but the school teaches children more than we do here at home ... As parents we do not have the time to do any homework with them, but an elder sibling or sister-in-law sometimes does that.

Mrs Gato, the household head of the third case study family, echoed this same sentiment: 'Yes, education starts here at home and the school takes the process further, since school education is the life line of every family'. 
Teachers held similar views about parents. In a feedback meeting with teachers, I asked why they did not involve parents in meaningful ways around their children's learning. The senior teacher Mrs Njanga and one of the teachers laughed casually and said that these parents were completely different from the urban parents I was used to. It was apparent that other teachers shared that view as they approvingly nodded in agreement. These parents knew nothing, they said, and it was pointless to even try and involve them. In the course of the study, however, the views of the parents and teachers shifted significantly.

The two groups came together at a meeting at the school arising from a request from the Parents Teachers Committee (PTC) for the researcher to explain the aims of the study. More than 50 parents and all pupils and teachers attended a meeting held outdoors under the trees on a Thursday, the day when people do not work in their fields. The Head teacher and the Chairman of the PTC took turns in chairing the proceedings. The importance of this meeting lies in its transformative potential. By taking on board the voices of the parents, the teachers created opportunities for genuine partnership. The greater receptiveness of the teachers to the parental perspective in turn acted as a catalyst for increased participation on the part of parents in their children's schooling. The extracts from the speeches offered by both teachers and parents in the course of the meeting demonstrate a marked shift in attitudes.

Mrs Ukama, the head of the school and the principal host, started by drawing attention to the critical role of children's home practices and talked about the wider significance of the meeting, which she considered a form of professional development for the teachers as well as an opportunity for developing a sustainable school-parent partnership. Mr Mazhambe, the deputy head, had also shifted from his initial position that parents had no part to play in the education of their children. In talking about the lessons learned from the study, he commented:

We were reminded of concepts we learnt at teacher's college when we were training and concepts, I should admit, we did not apply every day in our teaching. We tended to relegate the place of children's home experiences to the periphery of their learning, and yet this is what teaching from the known to the unknown is all about ... We were also happy about the way the study encouraged you parents to take more interest in the school in general and children's school work in particular. Yes, we converge at the child, and therefore let's start from here, and it will benefit children tremendously.

At this meeting with parents, teachers were beginning to respond to parents as customers and partners (Docking 1990), a relationship in which parents have the right to information on their child from the school, and to discuss educational content and methods. The parents' reactions suggested a similar shift and an unexpected willingness to accept their role as educational and social partners (quite radical in the context of earlier ambivalent attitudes). Mr Gamba, a respected community elder, asserted the respect which parents felt for learning:

As I stand here I am also one overflowing with joy. I am thrilled about the great event that has brought great happiness to our school. We have never seen anything like this, and therefore before I make my presentation I would like to lead you into song... This means we have just had a newborn baby just like Jesus here at our school, Chitubu. It is a pleasant miracle that has happened here ... Children have come with reports of this project home and the benefits it has brought. When I then went on to find out more about this, then people told me that we had had a new child, a king born among us, and I want to stop here.

This religious imagery underlines the value the community attached to their children's education. What comes through is the joy of parents in actively participating in the educational triangle, in marked contrast to the views expressed in the interviews earlier that 
they had no role to play in the development of school literacy. This enthusiasm clearly has the potential to be transformed into participation in the day-to-day activities of the school. The meeting 'captured the logic' of the views of the research participants (Hammersley 2000,395) - teachers, parents and pupils - established a common interest around the child's learning rather than seeing school curriculum activities through the blinkers of traditional educational assumptions.

Earlier comments from both parties had suggested that attempts to establish a partnership between parents and teachers would be problematic. This was not the case. The meeting demonstrated, above all, the readiness of parents to become partners in literacy, as demonstrated by their independent initiative to invite the researcher to talk about the details of the research. The teachers, for their part, had quickly realised the potential benefits of the partnership and welcomed this suggestion with enthusiasm. The meeting pointed to ways in which children, teachers and parents could work together. Suggestions emerging from the subsequent discussion included the establishment of Literacy Day events and the need for input from the school or from the findings of the study on better methods of handling their children's literacy needs at home. The senior teacher, Mrs Njanga, said that teachers were looking forward to the day when they could send children with reading homework to be supervised by parents.

Grade 1 children also demonstrated a shared understanding of the importance of literacy in a sketch improvised and performed by children as part of the same event:

$\mathrm{Hi}$, my friend. What do you want to become when you grow up?

Bus conductor.

What about you, my friend? What do you want to be when you grow up?

Nurse.

And you, my friend, what do you want to do when you grow up?

Builder.

Hello, my friend. What do you want to become when you grow up?

Teacher.

And you, my friend. What do you want to become when you grow up?

Dressmaker.

Hey, my friend. What do you want to become when you grow up?

When I grow up I would like to be like Mr Ngwaru bringing you books while learning far abroad.

Yes, when I grow up I would like to be like Mr Ngwaru bringing you books while learning far abroad.

\section{Conclusion}

In this paper we have argued that most studies of sub-Saharan African classrooms exclude the voices of key stakeholders in literacy and schooling - pupils and parents. In contrast, the examples we have introduced from Ghana and Zimbabwe highlight the ways in which pupil and parent perspectives can deepen our understanding of classroom interaction at the same time as validating the findings of existing research; in some cases, they can also help to challenge conventional wisdom. 
Many researchers speculate on the possible consequences of teacher words or actions for classroom outcomes. Authors such as Andoh-Kumi, (1998), Ejieh (2004) and Wilmot (2003), for instance, conclude that the use of familiar languages in African classrooms both facilitates literacy and helps pupils learn more effectively. The inclusion of the children's voices helps us understand why this should be the case. Their comments illustrate, among other things, how the use of English - an unfamiliar language as medium of instruction creates anxiety and stalls effective classroom participation. Student views about the use of selective teacher attention provide unambiguous evidence of the strength of feeling against favouritism, while comments from children provide evidence of how home circumstances impact on access to educational resources and the ability to fully participate in schooling. In all cases, pupil voices validate the findings of other studies, but at the same time, they add depth and texture to our understanding of why this should be the case.

By the same token, the inclusion of Zimbabwean parent voices moves us from speculation about their situation and its possible impact on their children's learning to a more nuanced understanding of their 'ruling passions' - their priorities and immediate needs. Equally important, the evidence of the emancipatory effects of parent engagement in dialogue with teachers challenges the widespread assumption that African parents lack the necessary willingness or 'capital' to engage actively in their children's education.

Children's underperformance can, of course, be attributed to a wide range of factors including poorly motivated and trained teachers, large class sizes and inappropriate pedagogies. The inclusion of all stakeholders has the potential to support or refute the findings of survey and observational studies; it is also likely to lead to a deeper and more nuanced understanding of what is taking place. This understanding, in turn, holds important clues for the development of more effective pedagogies in sub-Saharan African classrooms.

\section{References}

Ackers, J., and F. Hardman. 2001. Classroom interaction in Kenyan primary schools. Compare 31, no. 2: 245-61.

Alidou, H., and B. Brock-Utne. 2005. Teaching in a familiar language. Optimizing learning and education in Africa - the language factor: A stock-taking research on mother tongue and bilingual education in sub-Saharan Africa. Paper presented at the Conference on Bilingual Education and the Use of Local Languages, August 3-5, 2005, in Windhoek, Namibia, Association for the Development of Education in Africa (ADEA), Deutsche Gesellschaftfür Technische Zusammenarbeit, UNESCO Institute for Education.

Altbach, P.G., and G.P. Kelly. 1988. Textbooks in the third world: Policy, content and context. New York: Garland Publishing.

Andoh-Kumi, K. 1998. Medium of instruction at the basic education level: Does it matter? Legon Journal of the Humanities 11: 119-46.

$\mathrm{Au}$, K.H. 1998. Social constructivism and the school literacy learning of students of diverse backgrounds. Journal of Literacy Research 30, no. 2: 297-319.

Baker, C. 2001. Foundations of bilingual education and bilingualism. 3rd ed. Clevedon, UK: Multilingual Matters.

Baker, C. 2006. A parents' and teachers' guide to bilingualism. Clevedon, UK: Multilingual Matters.

Barton, D., and M. Hamilton. 1998. Local literacies. Reading and writing in one community. London: Hamilton.

Bloome, D., S.P. Carter, S. Otto, and N. Shuart-Faris. 2005. Discourse analysis and the study of classroom language and literacy events - A microethnographic perspective, Mahwah, $\mathrm{NJ}$ : Lawrence Erlbaum Associates.

Brock-Utne, B. 2001. Education for all - In whose language? Oxford Review of Education 27, no. 1: 115-34.

Bunyi, G. 1997. Multilingualism and discourse in primary school mathematics in Kenya. Language, Culture and Curriculum 10, no. 1: 52-65. 
Bunyi, G.W. 2005. Language classroom practices in Kenya. In Decolonisation, globalisation: Language-in-education, policy and practice, ed. A.M.Y. Lin and P.W. Martin, 131-52. Clevedon, UK: Multilingual Matters.

Chick, J.K. 1996. Safe-talk: Collusion in apartheid education. Society and the language classroom, ed. H. Coleman, 21-39. Cambridge: Cambridge University Press.

Christie, P., K. Harley, and A. Penny. 2005. Case studies from sub-Saharan Africa. In International handbook of continuing professional development, ed. C. Day and J. Sachs, 167-90. Buckingham, UK: Open University Press.

Creemers, B. 1994. The effective classroom. London: Cassell.

Cummins, J. 2001. Negotiating identities: Education for empowerment in a diverse society. Ontario, CA: California Association for Bilingual Education.

Daley, T.C., S.E. Whaley, M.E. Sigman, D. Guthrie, C.G. Neumann, and N. Bwibo. 2005. Background and classroom correlates of child achievement, cognitive, and behavioural outcomes in rural Kenyan schoolchildren. International Journal of Behavioural Development 29, no. 5: 399408.

Dei, G.J.S. 2005. Social difference and the politics of schooling in Africa: A Ghanaian case study. Compare 35, no. 3: 227-45.

Docking, J. 1990. Primary schools and parents. Rights, responsibilities, and relationships. London: Hodder \& Stoughton.

Eder, D., and L. Fingerson. 2002. Interviewing children and adolescents. In Handbook of interview research: Context and methods, ed. J.F. Gubrium and J.A. Holstein, 181-201. Thousand Oaks, CA: Sage Publications.

Ejieh, M.U.C. 2004. Attitudes of student teachers towards teaching in mother tongue in Nigerian primary schools: Implications for planning. Language, Culture and Curriculum 17, no. 1: 7381.

Farrell, J.P., and S.P. Heyneman. 1989. Textbooks in the developing world. Washington, DC: World Bank.

Fuller, B. 1987. What school factors raise achievement in the Third World? Review of Educational Research 57, no. 3: 255-92.

Fuller, B., and C.W. Snyder. 1991. Vocal teachers, silent pupils? Life in Botswana classrooms. Comparative Education Review 35, no. 2: 274-94.

Hall, E. 1983. Ghanaian languages. Accra, Ghana: Asempa Publishers.

Hammersley, M. 2000. The relevance of qualitative research. Oxford Review of Education 26, nos. 3 and 4: 393-405.

Harley, C.P., and A. Penny. 2005. Case studies from sub-Saharan Africa. In International handbook of continuing professional development, ed. C. Day and J. Sachs, 167-90. Buckingham, UK: Open University Press.

Heyneman, S.P., J. Farrell, and M. Sepulveda-Stuardo. 1981. Textbooks and achievements in developing countries: What we know. Journal of Curriculum Studies 13, no. 3: 227-46.

Heyneman, S.P., and D.T. Jamison. 1980. Student learning in Uganda: Textbook availability and other factors. Comparative Education Review 24, no. 2: 206-20.

Hurst, V., and J. Joseph. 1998. Supporting early learning: the way forward. Buckingham, UK: Open University Press.

Johnson, K.E. 1995. Understanding communication in second language classrooms. Cambridge: Cambridge University Press.

Martin, P.W. 1999. Bilingual unpacking of monolingual texts in two primary classrooms in Brunei Darussalam. Language and Education 13, no. 1: 38-58.

Neuman, S.B. 1999. Books make a difference: A study of access to literacy. Reading Research Quarterly 34, no. 3: 286-311.

Neuman, S.B. and D. Celano. 2001. Access to print in low-income and middle-income communities: An ecological study of four neighbourhoods. Reading Research Quarterly 36, no. 1: 826.

Ngwaru, J.M. 2008. Literacy and learning at home and school in a rural Zimbabwean community. Unpublished PhD thesis, University of Reading, UK.

Nutbrown, C., P. Hannon, and A. Morgan. 2005. Early literacy work with families: Policy, practice and research. London: Sage Publications.

Opoku-Amankwa, K. 2008. Textbooks, classroom communication and literacy development in a multilingual school in Ghana. Unpublished PhD thesis, University of Reading, UK. 
Osei, G.M. 2003. Issues arising from an examination of the Junior Secondary Reform of 1987 in Ghana. Educational Studies 29, nos. 2 and 3: 141-77.

Rabušicová, M., and K. Emmerová. 2002. The role of parents as educational and social partners of schools in the Czech Republic: Legislation and media analysis. European Educational Research Journal 1, no. 3: 480-96.

Ramirez, J.D., S.D. Yuen, and D.R. Ramey. 1991. Final report: Longitudinal study of structured English immersion strategy, early-exit and late-exit transitional bilingual education programs for language-minority children. US Department of Education Contract No. 300-87-0156. Mateo, CA: Sguirre International.

Rubagumya, C., ed. 1990. Language in education in Africa: A Tanzanian perspective. Clevedon, UK: Multilingual Matters.

Rubagumya, C., ed. 1993. Teaching and researching language in African classrooms. Clevedon, UK: Multilingual Matters.

Tabulawa, R. 1997. Pedagogical classroom practice and the social context: The case of Botswana. International Journal of Educational Development 17, no. 2: 189-204.

Thomas, W., and V. Collier. 2002. Summary of findings across all research sites. A national study of school effectiveness for language minority students' long-term achievement. Final Report: Project 1.1. Santa Cruz, CA: Centre for Research on Education, Diversity and Excellence, University of California.

Williams, J.D., and G.C. Snipper. 1990. Literacy and bilingualism. New York: Longman.

Wilmot, E.M. 2003. Stepping outside the ordinary expectations of schooling: Effect of school language on the assessment of educational achievement in Ghana. Paper presented at the 47th annual conference of the Comparative and International Education Society (CIES 2003), March 12-16, in New Orleans, LA.

Wolfendale, S. 1983. Parental participation in children's development and education. London: Gordon and Breach. 